\title{
Sebastian Gnat Powierzchniowy a katastralny system opodatkowania nieruchomości w Polsce
}

\begin{tabular}{|c|c|}
\hline \multicolumn{2}{|c|}{$\begin{array}{l}\text { Area versus value-based taxation of real estate in Poland } \\
\text { The article explores the economic aspects of area and value-based taxation of Polish real estate. It begins } \\
\text { with the presentation of information on the conditions of property taxation in Poland. Next, a review of the } \\
\text { research on the cadastral tax is provided, as well as the assumptions of the econometric model used for } \\
\text { mass valuation of the analysed real estate. The main part of the article contains the results of the simula- } \\
\text { tion of replacing the property tax with an ad valorem one. Particular attention is given to the impact of the } \\
\text { cadastral tax rate on the revenues of municipalities and changes in the tax burden on individual properties. } \\
\text { The main aim of this study was to show the importance of the proper setting of the ad valorem tax rate in } \\
\text { the process of reforming the property taxation system. }\end{array}$} \\
\hline DOI & https://doi.org/10.31268/StudiaBAS.2021.08 \\
\hline Słowa kluczowe & $\begin{array}{l}\text { opodatkowanie nieruchomości w Polsce, podatek katastralny, podatek } \\
\text { od nieruchomości, powszechna taksacja nieruchomości }\end{array}$ \\
\hline Keywords & $\begin{array}{l}\text { taxation of real estate in Poland, cadastral tax, property tax, general } \\
\text { property valuation }\end{array}$ \\
\hline 0 autorze & $\begin{array}{l}\text { doktor nauk ekonomicznych, Uniwersytet Szczeciński, Instytut } \\
\text { Ekonomii i Finansów, Katedra Ekonometrii i Statystyki • } \\
\square \text { sebastian.gnat@usz.edu.pl • ORCID 0000-0003-0310-4254 }\end{array}$ \\
\hline
\end{tabular}

\section{Wstęp}

Podatki od nieruchomości należą do najstarszych danin publicznych i w zależności od podstawy opodatkowania można je podzielić na podatki liczone od powierzchni nieruchomości lub od wartości nieruchomości. W Polsce podstawą opodatkowania jest zasadniczo powierzchnia nieruchomości. Podatek od nieruchomości jest w całości dochodem własnym gmin, przez nie jest także kształtowany, jednakże w zakresie ograniczonym przepisami prawa. Wysokość podatku jest określana przez radę gminy w formie stosownej uchwały publikowanej w dzienniku urzędowym województwa. Podatek od nieruchomości to podatek lokalny, a zatem charakterystyczne są dla niego:

- ścisłe powiązanie z obszarem, na którym obowiązuje,

- stosunkowo prosta konstrukcja,

- związek między przeznaczeniem nieruchomości czy sposobem jej wykorzystania a zadaniami władz lokalnych.

Podatek od nieruchomości wraz z podatkami rolnym i leśnym tworzą w Polsce system podatków pobieranych w związku z posiadaniem i użytkowaniem w określonych celach nieruchomości zabudowanych i niezabudowanych¹. Ten pierwszy jest jednak w literaturze często

1 P. Felis, Konsekwencje reformy systemu podatków od nieruchomości w Polsce [w:] Konsekwencje zmiany obciq̨żeń podatkowych w Polsce, red. J. Głuchowski, K. Piotrowska-Marczak, J. Fila, Difin, Warszawa 2013, s. 150. 
krytykowany. Zdaniem K. Wójtowicz ${ }^{2}$ obecny system podatków majątkowych, w tym system opodatkowania nieruchomości (podatki: od nieruchomości, rolny i leśny), nie spełnia wymogów gospodarki rynkowej, przez co przyczynia się do trudności finansowych jednostek samorządu terytorialnego (JST). Wspomniane podatki nie realizują w Polsce funkcji pozafiskalnej, nie są też wykorzystywane jako instrument prowadzenia racjonalnej polityki gospodarowania przestrzenią. Jak wskazuje P. Felis: „Konstrukcja wszystkich trzech podatków, ukształtowana w zupełnie innym ustroju, nie odpowiada obecnie wymogom gospodarki rynkowej"3.

Samorządy lokalne realizują wiele przydzielonych im ustawowo zadań, finansowanych m.in. z dochodów uzyskiwanych z podatków lokalnych. Potrzeby jednostek samorządu terytorialnego w tym zakresie jednak nieprzerwanie rosną i obecnie obowiązujące podatki związane z posiadaniem nieruchomości są niewystarczające, by te potrzeby zaspokoić. Reforma opodatkowania nieruchomości jest więc konieczna, lecz wymaga wielu działań zarówno politycznych oraz organizacyjnych, jak i naukowych. Niezwykle istotne w tym zakresie są badania o podłożu ekonomicznym. Można bowiem dyskutować, czy i jak wprowadzić opodatkowanie wartości nieruchomości, jednakże szczególnie ważne wydaje się to, jakie skutki ekonomiczne może wywołać zastąpienie podatków: od nieruchomości, rolnego i leśnego, jednym podatkiem - katastralnym.

Aspekt ekonomiczny wprowadzenia podatku od wartości nieruchomości, zwanego także podatkiem katastralnym lub podatkiem ad valorem, może być rozpatrywany z różnych perspektyw. Jeśli chodzi o budżety gmin, to należy ocenić, czy zasadnicza zmiana podstawy opodatkowania nieruchomości stworzy nowe, bardziej stabilne i efektywne źródło dochodów. Jeżeli spojrzeć na podatek ad valorem z perspektywy podatników, to staną oni przed koniecznością płacenia nowej daniny publicznej. W obu tych przypadkach najważniejszymi elementami są wartość nieruchomości oraz stawka podatku katastralnego. Te dwa elementy zadecydują o sukcesie lub porażce opodatkowania wartości nieruchomości.

Celem badania podjętego w niniejszym opracowaniu jest przedstawienie wpływu zarówno wartości nieruchomości, jak i stawki podatku ad valorem na budżet gminy i obciążenia podatkiem pojedynczych przedmiotów opodatkowania. Zaprezentowane zostaną wyniki wskazujące, jak różne stawki podatku katastralnego oddziałują na potencjalne dochody gmin i wysokość podatków naliczanych od konkretnych nieruchomości. Przypuszczalnie w pierwszej fazie wprowadzania podatku katastralnego zostałaby opodatkowana wartość gruntów, ponieważ najlepiej rozwiniętą bazą danych o nieruchomościach jest obecnie system informacji o gruntach w postaci ewidencji gruntów. Zgodnie z tym tokiem rozumowania badaniem objęto więc tylko grunty. Przedmiot analizy stanowią dwa zbiory danych. Jeden z nich obejmuje ponad 1,6 tys. działek gruntu zlokalizowanych w jednej z gmin wiejskich województwa zachodniopomorskiego, drugi - blisko 1,5 tys. działek gruntu w Szczecinie. Wszystkie omawiane działki są przeznaczone lub wykorzystywane do celów mieszkaniowych. Nie stanowią obszernych zbiorów i można znaleźć badania oparte na większej liczbie nieruchomości, jednakże wnioski płynące z analizy wybranych działek gruntu są potwierdzeniem rezultatów badań prowadzonych w in-

2 K. Wójtowicz, Analiza potencjalnych skutków reformy systemu opodatkowania nieruchomości w Polsce [w:] Finanse publiczne, red. A. Pomorska, Wydawnictwo UMCS, Lublin 2006.

3 P. Felis, Konsekwencje reformy..., s. 150. 
nych częściach Polski ${ }^{4}$. Przykładowo w publikacji na temat podatku katastralnego M. Głuszaka i B. Marony autorzy skupiają się na nieruchomościach w Krakowie i podejmują trud oceny skutków wprowadzenia podatku katastralnego. Dochodzą do wniosku, że wysokość stawki podatku od wartości nieruchomości jest głównym czynnikiem wpływającym na zmianę obciążeń podatkowych. Wartością dodaną badania podjętego w niniejszej pracy - w odróżnieniu od badań o charakterze ogólnym ${ }^{5}$ - jest to, że pozwala ono na spojrzenie na kwestię wprowadzenia podatku katastralnego z perspektywy pojedynczych przedmiotów opodatkowania. Dzięki temu możliwe jest odkrycie nowych wątków ${ }^{6}$ dotyczących tego, jak może się zmienić opodatkowanie nieruchomości w wyniku zastąpienia obecnie istniejących podatków podatkiem naliczanym od wartości nieruchomości.

\section{Podatek katastralny w badaniach naukowych}

Wyzwania i trudności związane z podatkiem katastralnym, potrzeby finansowe JST, które ten podatek miałby zaspokajać, czy skutki reformy opodatkowania nieruchomości w Polsce są z perspektywy badań naukowych problemem o zasięgu głównie krajowym. Na przestrzeni ponad 20 lat przeprowadzono analizy o różnym stopniu szczegółowości, mające przybliżyć problematykę zastąpienia podatków: od nieruchomości, rolnego i leśnego, podatkiem od wartości nieruchomości. Badacze zagadnienia W.J. Brzeski i R. Frenzen zwracali uwagę, że wprowadzenie podatku katastralnego może poprawić strukturę finansów publicznych, ponieważ pozwoli na stworzenie stabilnego i wydajnego źródła dochodów publicznych7. Według I. Pietraszko dzięki zmianom w opodatkowaniu nieruchomości samorządy zdobędą środki na realizację zadań, które otrzymały w wyniku reformy administracyjnej kraju ${ }^{8}$. Bardzo szeroko na temat przekształcenia opodatkowania nieruchomości pisał L. Etel ${ }^{9}$. Już ponad 20 lat temu podkreślał, że obecny kształt systemu opodatkowania nieruchomości wymaga szybkiej i gruntownej przebudowy. Głos ten nie był odosobniony. Na konieczność uporządkowania i ujednolicenia przepisów w zakresie podatku od nieruchomości od kilkunastu lat zwraca uwagę m.in. A. Milewska ${ }^{10}$. Także P. Felis ${ }^{11}$ wskazywał na rozdźwięk między postulatami wprowadzenia podatku ad valorem

4 M. Głuszak, B. Marona, Podatek katastralny. Ekonomiczne uwarunkowania reformy opodatkowania nieruchomości, Poltext, Warszawa 2015.

5 P. Felis, Konsekwencje reformy...

6 M. Głuszak, B. Marona, op. cit.; S. Gnat, Analysis of the Effects of Replacing Current Property Tax with Ad Valorem Property Tax in a Sample Municipality, „Folia Oeconomica Stetinensia” 2009, t. 8, nr 1, s. 82-98.

7 W.J. Brzeski, R. Frenzen, Uzasadnienie reformy formuły ad valorem w gospodarkach transformacji, „Świat Nieruchomości" 1999, nr 28

8 I. Pietraszko, Czy powinniśmy obawiać się podatku od wartości nieruchomości? , "Samorząd Terytorialny" 2003, $\mathrm{nr} 12$.

9 L. Etel, Reforma opodatkowania nieruchomości w Polsce, Wydawnictwo Temida 2, Białystok 1998.

10 A. Milewska, Problemy opodatkowania nieruchomości w Polsce - przegląd wybranych aspektów, „Annales Universitatis Mariae Curie-Skłodowska. Sectio H. Oeconomia" 2016, t. 50, nr 1, s. 391-398, https://doi. org/10.17951/h.2016.50.1.391.

11 P. Felis, System opodatkowania nieruchomości w Polsce , „Infos" 2012, 14(128), Biuro Analiz Sejmowych. 
a działaniami w tym zakresie, których właściwie nikt nie podejmuje. Autor ten wymienił ponadto szereg przeszkód, które hamują reformę opodatkowania nieruchomości. Wśród nich znalazły się bariery: techniczne, formalnoprawne, polityczne, społeczne i finansowe.

Podatek katastralny nie jest rozwiązaniem idealnym ani pod każdym względem lepszym od obecnych rozwiązań podatkowych. Na jego wady i zalety wskazywała J. Piekut ${ }^{12}$. Z jednej strony wymieniała niedociągnięcia podatku katastralnego, a więc: skomplikowany proces określania wartości nieruchomości, koszt wprowadzenia nowego systemu opodatkowania nieruchomości czy potencjalny znaczny wzrost obciążeń podatkowych. Z drugiej strony wyliczała korzyści tego rozwiązania: większą efektywność podatku katastralnego, wyższy poziom sprawiedliwości podatkowej oraz zwiększenie roli mechanizmów rynkowych w obrocie nieruchomościami. Badacze zainteresowani zagadnieniem podatku ad valorem analizowali także jego funkcjonowanie w innych państwach ${ }^{13}$. W pracach na ten temat wskazywano m.in., że doświadczenia państw, w których stosuje się katastralny system opodatkowania nieruchomości, potwierdzają zasadność wprowadzenia takiego rozwiązania w Polsce. Rozważania takie prowadzili choćby: M. Głuszak, B. Marona i P. Oleksy ${ }^{14}$. Autorzy ci zwrócili uwagę na obecne rozwiązania podatkowe, ekonomiczną i przestrzenną efektywność podatku od nieruchomości i jego sprawiedliwość. Podkreślali potrzebę prowadzenia większej liczby badań nad podatkiem od nieruchomości w aspekcie ekonomicznym.

Ważnym elementem badań nad opodatkowaniem wartości nieruchomości jest także kwestia potencjalnej zmiany obciążeń podatkowych. Obecnie maksymalne stawki podatku od nieruchomości określane przez Ministra Finansów mogą być obniżane przez uchwały rad gmin. Z badań prowadzonych przez A. Małkowską, A. Telegę, M. Głuszaka i B. Maronę ${ }^{15}$ wynika, że w zależności od badanego obszaru metropolitalnego i typu podatku faktyczne średnie stawki stosowane w gminach kształtują się w przedziale 0,46-0,96 maksymalnej stawki ministerialnej. Oznacza to, że w poszczególnych gminach wysokość podatku od nieruchomości o tej samej powierzchni może się różnić kilkukrotnie. W przypadku podatku katastralnego różnice w obciążeniu podatkowym nieruchomości mogą być o wiele większe. Przyjęcie jednej stawki podatku dla jednego typu nieruchomości w skali kraju może spowodować, że w jednej gminie podatek od nieruchomości będzie kilkadziesiąt razy wyższy niż w innej - ze względu na różnice w wartości nieruchomości w różnych częściach państwa.

12 J. Piekut, Wady i zalety wprowadzenia podatku katastralnego, "Kwartalnik Naukowy Uczelni Vistula” 2014, nr 3(41), s. 82-90.

13 M. Hełdak, A. Stacherzak, V. Baumane, Real Estate Value Tax Based on the Latvian Experience, "Real Estate Management and Valuation" 2014, t. 22, nr 4, s. 60-67, https://doi.org/10.2478/remav-2014-0037; E. Laskowska, Property Tax Systems in Selected European Union Countries and the Proposed Tax Reform in Poland, "Scientific Journal Warsaw University of Life Sciences - SGGW. Problems of World Agriculture" 2015, t. 15(30), nr 4, s. 127-136.

14 M. Głuszak, B. Marona, P. Oleksy, Non-Fiscal Incentives and Challenges of Property Tax Reform in Poland, „World of Real Estate Journal" 2013, nr 4(86).

15 A. Małkowska et al., Spatial Interdependence in Property taxation. The Case of Polish Municipalities, „Equilibrium. Quarterly Journal of Economics and Economic Policy" 2018, t. 13, nr 2, s. 265-283, https://doi.org/10.24136/ eq.2018.014. 
Literatura poświęcona opodatkowaniu wartości nieruchomości jest bardzo bogata i różnorodna. Przedmiotem prowadzonych badań są: wady i zalety podatku ad valorem, trudności i potencjalne skutki ekonomiczne związane z reformą opodatkowania nieruchomości, a także rozwiązania stosowane w innych państwach. W niniejszym opracowaniu podjęto temat wpływu stawki podatku katastralnego na sytuację ekonomiczną w dwóch różnych gminach, w których wartość nieruchomości jest odmienna.

\section{Masowa wycena nieruchomości}

Podstawą opodatkowania nieruchomości w przypadku podatku ad valorem ma być wartość katastralna nieruchomości. Wartość ta, zgodnie z ustawą z dnia 21 sierpnia 1997 r. o gospodarce nieruchomościami ${ }^{16}$, ma zostać ustalona w procesie powszechnej taksacji nieruchomości. Według art. 162 ust. 1 tej ustawy w wartościach katastralnych, ustalonych w procesie powszechnej taksacji nieruchomości, powinny być uwzględnione różnice, jakie występują między poszczególnymi nieruchomościami, oraz zbliżenie do wartości rynkowej możliwe do uzyskania z zastosowaniem zasad przyjętych do masowej wyceny. Wskazanie masowej wyceny jako narzędzia służącego do określenia podstawy opodatkowania nieruchomości otwiera możliwości korzystania z szerokiej gamy metod obliczeniowych. Jedną z takich metod jest szczeciński algorytm masowej wyceny nieruchomości (SAMWN). Można go przedstawić w formie równania ${ }^{17}$ :

$w_{j i}=w w r_{j} \cdot p o w_{i} \cdot w_{b a z} \prod_{k=1}^{K} \prod_{p=1}^{k_{p}}\left(1+a_{k p i}\right)$

gdzie:

$w_{j i}$ - wartość rynkowa (lub katastralna) i-tej nieruchomości w j-tej strefie atrakcyjności lokalizacji,

$w w r_{j}$ - współczynnik wartości rynkowej w j-tej strefie atrakcyjności lokalizacji $(j=1,2, \ldots, J)$,

J - liczba stref atrakcyjności lokalizacji (SAL),

pow - powierzchnia $i$-tej nieruchomości,

$w_{b a z}$ - cena $1 \mathrm{~m}^{2}$ najtańszego (nieuzbrojonego) gruntu na wycenianym obszarze,

$a_{k p i}$ - wpływ $p$-tej kategorii $k$-tego atrybutu dla $i$-tej nieruchomości $\left(k=1,2, \ldots, k ; p=1,2, \ldots, k_{p}\right)$,

$K$ - liczba atrybutów,

$k_{p}$ - liczba kategorii $k$-tego atrybutu.

16 Dz.U. 2020, poz. 1990, ze zm.

17 J. Hozer et al., Ekonometryczny algorytm masowej wyceny nieruchomości gruntowych, Uniwersytet Szczeciński, Stowarzyszenie Pomoc i Rozwój, Szczecin 1999; System kalibracji macierzy wpływu atrybutów w szczecińskim algorytmie masowej wyceny nieruchomości, red. M. Doszyń, Wydawnictwo Naukowe Uniwersytetu Szczecińskiego, Szczecin 2020. 
Równanie 1 ma postać multiplikatywną. Punktem odniesienia przy wycenie przeprowadzonej za pomocą algorytmu jest cena bazowa. To cena $1 \mathrm{~m}^{2}$ najtańszego i nieuzbrojonego gruntu na wycenianym obszarze. Można założyć, że jest to jednostkowa cena nieruchomości o najgorszych kategoriach atrybutów, do której dolicza się wpływ atrybutów wycenianych nieruchomości. Wpływ ten $a_{k p}$ może być określany ekspercko - przez rzeczoznawców majątkowych, lub za pomocą metod statystycznych i ekonometrycznych. Dla każdej strefy atrakcyjności lokalizacji wyznaczane są współczynniki wartości rynkowej $\left(w_{\text {w }}\right)$, które obrazują wpływ szeroko pojmowanej lokalizacji. Zabieg ten pozwala na włączanie do algorytmu czynników popytowych. Dwie bardzo podobne pod względem atrybutów nieruchomości mogą mieć różne wartości, jeśli są położone w różnych strefach atrakcyjności lokalizacji. Współczynnik wartości rynkowej dla j-tej strefy atrakcyjności lokalizacji to średnia geometryczna ilorazów rzeczywistych wartości nieruchomości i wartości hipotetycznych:

$w w r_{j}=\sqrt[n_{j}]{\prod_{i=1}^{n_{j}} \frac{w_{j i}^{r z}}{w_{j i}^{h}}}$

gdzie:

$w_{j i}^{r z}$ - wartość $i$-tej nieruchomości w j-tej strefie atrakcyjności lokalizacji określona przez rzeczoznawcę majątkowego,

$w_{j i}^{h}$ - wartość hipotetyczna $i$-tej nieruchomości w j-tej strefie atrakcyjności lokalizacji,

$n_{j}$ - liczba wycenionych przez rzeczoznawców nieruchomości reprezentatywnych w $j$-tej strefie atrakcyjności lokalizacji.

Wartości hipotetyczne $w_{j i}{ }^{h}$ obliczane są na podstawie (1), z pominięciem współczynników wartości rynkowej:

$w_{j i}^{h}=\operatorname{pow}_{i} \cdot c_{b a z} \prod_{k=1}^{K} \prod_{p=1}^{k_{p}}\left(1+a_{k p}\right)$

Jeśli są znane: wartości wylosowanych nieruchomości reprezentatywnych $\left(w_{j i}^{r z}\right)$, kategorie atrybutów i ich wpływ, cena bazowa $\left(c_{b a z}\right)$ i powierzchnie, to dla każdej strefy atrakcyjności można oszacować współczynniki wartości rynkowej jako średnią geometryczną z ilorazów rzeczywistych i hipotetycznych wartości nieruchomości.

Szczeciński algorytm masowej wyceny nieruchomości był przedmiotem licznych prac naukowych. Możliwości jego zastosowania do wyceny nieruchomości na terenach niezurbanizo- 
wanych zostały zaprezentowane przez I. Foryś i E. Putek-Szeląg ${ }^{18}$. Prowadzono także badania, których celem było usprawnienie działania SAMWN przez wykorzystywanie różnego typu miar statystycznych $^{19}$. Natomiast M. Doszyń podjął się zadania zwiększenia dokładności wycen masowych na podstawie modelu SAMWN20. Algorytm znalazł także praktyczne zastosowanie. Wykorzystano go w ocenie ekonomicznych skutków zmian w planie zagospodarowania przestrzennego dla miasta Szczecina, a następnie do aktualizacji opłat z tytułu użytkowania wieczystego gruntów.

\section{Symulacja zastąpienia aktualnego podatku od nieruchomości podatkiem katastralnym}

\section{Opis zbiorów nieruchomości stanowiących przedmiot badania}

Badanie wpływu zastąpienia podatku od nieruchomości podatkiem ad valorem na dochody gmin i obciążenia podatkowe właścicieli nieruchomości miało charakter symulacyjny. Analizie poddano dwie gminy: gminę miejską oraz gminę wiejską. W przypadku gminy wiejskiej dysponowano zbiorem danych o 1634 działkach gruntu przeznaczonych bądź wykorzystywanych do celów mieszkaniowych. Działki te stanowiły całość gruntów mieszkaniowych w analizowanej gminie. Drugi zbiór zawierał informacje o 1494 działkach gruntu również przeznaczonych do celów mieszkaniowych, w tym przypadku była to jednak część tego typu gruntów zlokalizowanych w analizowanej gminie miejskiej. Wybór działek nie był przypadkowy - wszystkie stanowiły, w czasie tworzenia zbioru danych, grunty wyceniane na potrzeby aktualizacji opłat rocznych z tytułu użytkowania wieczystego gruntów. Przedmiotem analizy były zatem jedynie grunty; ich zabudowy w ogóle nie brano pod uwagę. Dla tak zdefiniowanych zestawów gruntów ustalono, zgodnie z obowiązującymi w obu gminach w 2020 r. stawkami podatku od nieruchomości dla gruntów mieszkaniowych, bieżące obciążenia podatkowe. Na kolejnym etapie za pomocą opisanego algorytmu masowej wyceny określono wartości gruntów w gminie wiejskiej ${ }^{21}$ oraz gminie miejskiej ${ }^{22}$. Na wykresach 1 i 2 przedstawiono rozkłady wartości jednostkowych

18 I. Foryś, E. Putek-Szeląg, A Non-Classical Model of Mass Valuation of Agricultural Property, "Real Estate Management and Valuation" 2018, t. 26, nr 4, s. 90-101, https://doi.org/10.2478/remav-2018-0039.

19 K. Dmytrów, A. Gdakowicz, E. Putek-Szeląg, Statistical Relations of the Qualitative Attributes of Real Properties Subject to Mass Appraisal, „Folia Oeconomica Stetinensia” 2019, t. 19, nr 2, s. 25-37, https://doi.org/10.2478/ foli-2019-0011; K. Dmytrów, A. Gdakowicz, E. Putek-Szeląg, Methods of Analyzing Qualitative Variable Correlation on the Real Estate Market, "Real Estate Management and Valuation” 2020, t. 28, nr 1, s. 80-90, https:// doi.org/10.2478/remav-2020-0007.

20 M. Doszyń, Algorithm of Real Estate Mass Appraisal with Inequality Restricted Least Squares (IRLS) Estimation, „Journal of European Real Estate Research" 2020, t. 13, nr 2, s. 161-179, https://doi.org/10.1108/jerer-11-2019-0040.

21 S. Gnat, Powierzchniowy a katastralny system opodatkowania nieruchomości - symulacja wybranych skutków fiskalnych, „Annales Universitatis Mariae Curie-Skłodowska. Sectio H. Oeconomia” 2016, t. 50, nr 1, s. 371-380, https://doi.org/10.17951/h.2016.50.1.371.

22 System kalibracji.. 
Wykres 1. Rozkład wartości jednostkowych analizowanych działek gruntu - gmina wiejska

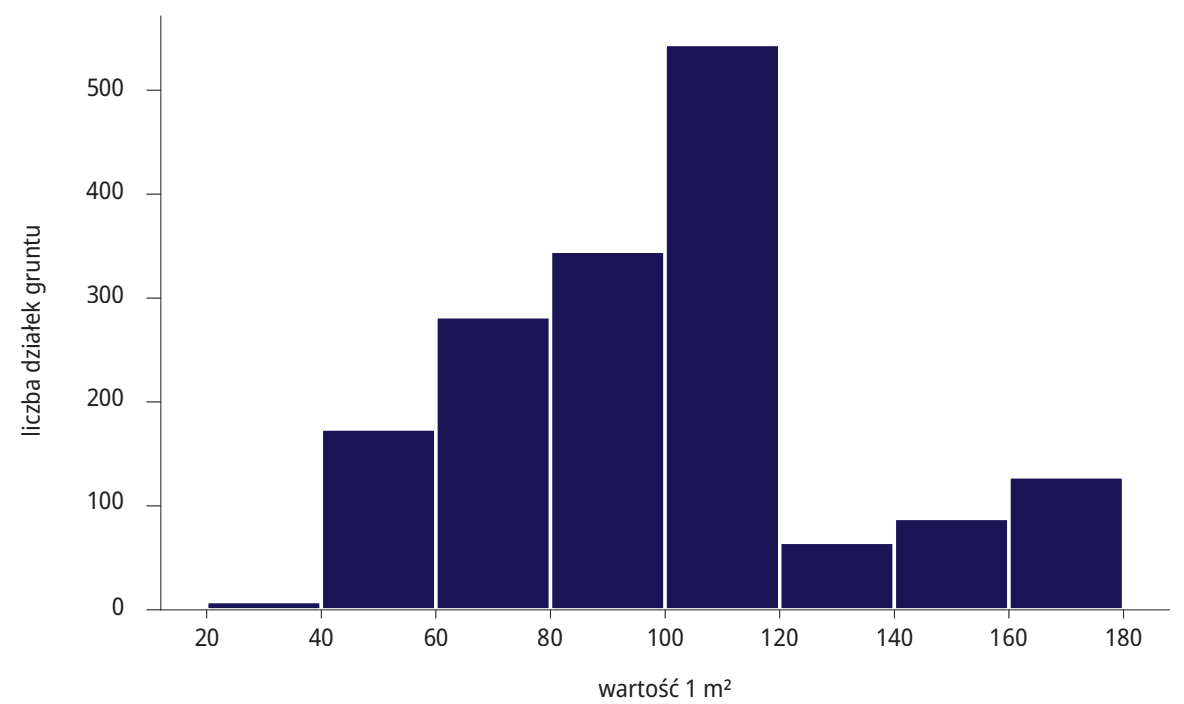

Źródło: opracowanie własne.

Wykres 2. Rozkład wartości jednostkowych analizowanych działek gruntu - gmina miejska

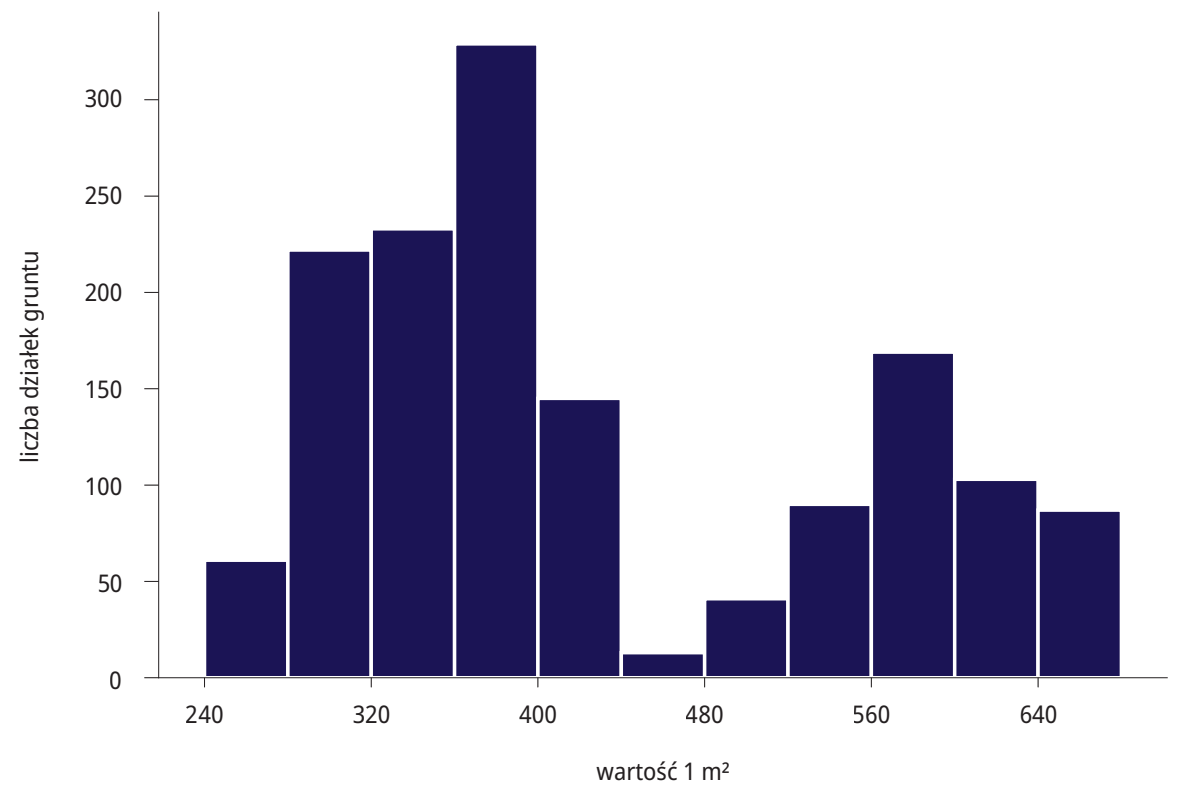

Źródło: opracowanie własne. 
gruntów w obu zestawach. Rozkłady tych wartości znacznie się różnią. W przypadku gminy wiejskiej dominowały działki o niższych wartościach jednostkowych, głównie w przedziale od 100 do $120 \mathrm{zł} / \mathrm{m}^{2}$. Z kolei działki zlokalizowane w gminie miejskiej składały się niejako na dwa oddzielne podzbiory. W pierwszym dominowały działki o wartości 360-400 zł/m², natomiast w drugim - 560-600 zł/m². Średnia wartość analizowanych działek z gminy miejskiej była ponadczterokrotnie wyższa od średniej wartości działek zlokalizowanych w gminie wiejskiej. Wybrane miary struktury obu analizowanych zbiorów przedstawiono w tabeli 1.

\section{Tabela 1. Wybrane miary struktury wartości jednostkowych analizowanych działek gruntu}

\begin{tabular}{|l|c|c|c|}
\hline \multicolumn{1}{|c|}{ Wyszczególnienie } & Jednostka & Gmina wiejska & Gmina miejska \\
\hline Liczba działek & - & 1634 & 1494 \\
\hline Średnia wartość jednostkowa & & 99,88 & 430,28 \\
\hline Odchylenie standardowe wartości jednostkowych & & 31,76 & 121,03 \\
\hline Minimalna wartość jednostkowa & & 23,52 & 241,26 \\
\hline Kwartyl pierwszy wartości jednostkowych & {$[$ zł/m²] } & 72,24 & 335,01 \\
\hline Mediana wartości jednostkowych & & 100,04 & 390,47 \\
\hline Kwartyl trzeci wartości jednostkowych & & 118,17 & 556,96 \\
\hline Maksymalna wartość jednostkowa & & 177,98 & 684,97 \\
\hline
\end{tabular}

Źródło: opracowanie własne.

\section{Symulacja zmian obciążeń podatkowych analizowanych nieruchomości}

W celu określenia wpływu wprowadzenia opodatkowania wartości nieruchomości na dochody gminy i obciążenia podatkowe działek gruntu zaproponowano kilka stawek podatku (tabela 2). Najpierw osobno rozpatrywano stawki dla obu analizowanych zbiorów. Przyjęto stawki w wysokości 100\% (stawka A), 200\% (stawka B) oraz 300\% (stawka C) bieżących wpływów z tytułu podatku od nieruchomości. W przypadku czwartej wersji opodatkowania nieruchomości, a więc stawki przedziałowej, zaproponowano rozwiązanie oparte na modelu angielskim ${ }^{23}$ - dla siedmiu przedziałów wartości działek gruntu zastosowano mnożniki stawki „podstawowej” A. Ponieważ w analizie nie można wykorzystać przedziałów obowiązujących w Anglii, przyjęto, że do każdego przedziału należy jedna siódma analizowanych działek z obu zbiorów. Granice poszczególnych przedziałów w takim rozwiązaniu są obecnie kwestią otwartą. Jak widać w tabeli 2, stawki procentowe podatków są wyższe w przypadku gminy wiejskiej, ponieważ dla zestawu gruntów w gminie wiejskiej odnotowano znacznie niższe wartości jednostkowe gruntów. Taka sytuacja jest jednym z głównych problemów ustalenia odpowiedniej stawki podatku katastralnego. Jeśli

23 E. Laskowska, op. cit., s. 131. 
obciążenia podatkowe podatkiem od nieruchomości różnią się w przypadku gruntów o tej samej powierzchni i o tym samym przeznaczeniu kilkukrotnie, to wartości jednostkowe gruntów mogą w skali kraju różnić się kilkudziesięciokrotnie. To sprawia, że przy jednakowej stawce procentowej podatku od wartości nieruchomości różniłyby się także wysokości podatku w gminach o skrajnie różnych poziomach wartości gruntu. Należy przypuszczać, że takie dysproporcje nie zostałyby przyjęte ze zrozumieniem przez podmioty, na których ciąży obowiązek uiszczenia podatku od nieruchomości. Próba ograniczenia tego efektu nie byłaby zaś dobrze odebrana przez społeczeństwo, ponieważ wiązałoby się to - co przedstawiono w tabeli 2 - z niższymi stawkami w gminach o wyższych wartościach nieruchomości. Z kolei zastosowanie stawek progresywnych, jak w modelu brytyjskim, jeszcze bardziej zwiększyłoby różnice w obciążeniach podatkowych nieruchomości.

\section{Tabela 2. Stawki podatku ad valorem zastosowane w analizach}

\begin{tabular}{|c|c|c|c|c|}
\hline & Stawka A & Stawka B & Stawka C & $\begin{array}{c}\text { Stawka dla przedziałów wartości działek } \\
\text { gruntu (mnożnik stawki A) }\end{array}$ \\
\hline Gmina wiejska & $0,27 \%$ & $0,54 \%$ & $0,80 \%$ & \multirow[b]{2}{*}{$\begin{array}{l}\text { do } 31725 \text { zł - } 1 \\
\text { od } 31726 \text { do } 63541 \text { zł- 1,17 } \\
\text { od } 63542 \text { do } 82762 \text { zł- } 1,33 \\
\text { od } 82763 \text { do } 109110 \text { zł- } 1,5 \\
\text { od } 109111 \text { do } 135259 \text { zł- } 1,83 \\
\text { od } 135260 \text { do } 178263 \text { zł- -2,17 } \\
\text { od } 178264 \text { do } 288902 \text { zł- -2,5 } \\
\text { od } 288903 \text { zł - } 3\end{array}$} \\
\hline Gmina miejska & $0,11 \%$ & $0,23 \%$ & $0,34 \%$ & \\
\hline
\end{tabular}

Źródło: opracowanie własne.

Zastosowanie wspomnianych stawek z jednej strony sprawia, że będą zapewnione zakładane przyrosty wpływów do budżetów gmin, ale z drugiej strony wywołuje różne zmiany obciążeń podatkowych poszczególnych działek gruntu. Na wykresach 3 i 4 przedstawiono rozkłady przyrostów opodatkowania analizowanych działek gruntu w gminie wiejskiej. Kolorem białym oznaczono tę część zbioru, dla której odnotowano spadek podatku (przyrosty mniejsze niż 1). Kolorem niebieskim wyróżniono tę część, w przypadku której nastąpił wzrost obciążenia wynikający z zastąpienia podatku od nieruchomości podatkiem ad valorem. Jeśli chodzi o stawkę A, która miała zagwarantować brak zmian w dochodach gminy, to w wyniku jej zastosowania nastąpiłby wzrost podatku dla 57\% działek zlokalizowanych w gminie wiejskiej i 34\% działek w gminie miejskiej. Oznacza to, że dość znacząca część podatników mogłaby liczyć na mniejsze obciążenia podatkowe w wyniku reformy opodatkowania nieruchomości, przy założeniu stawki zapewniającej neutralność z punktu widzenia dochodów gminy. To, jak duża by to była część, zależy oczywiście od struktury wartości nieruchomości. Jeśli jednak przyjąć założenie (chyba bliższe rzeczywistym oczekiwaniom), że podatek od wartości nieruchomości ma zwiększyć dochody gmin, to wysokość podatku dla większości gmin nie może zmaleć, wręcz przeciwnie - powinna wzrosnąć. Zastosowanie stawek B oznaczałoby zwiększenie obciążeń w przypadku 98\% działek z gminy wiejskiej oraz $100 \%$ z gminy miejskiej. Przy stawce C, teoretycznie trzykrotnie zwiększa- 
jącej dochody gmin, należałoby się liczyć ze wzrostem podatku dla niemal wszystkich działek (poza jedną działką w gminie wiejskiej). Dość obiecująco wygląda zmiana obciążeń i wpływów do budżetów gmin w przypadku stawki przedziałowej podatku od wartości nieruchomości. W zbiorze działek gruntu zlokalizowanych w gminie zarówno wiejskiej, jak i miejskiej odnotowano wzrost dochodów podobny do wzrostu w wyniku wprowadzenia stawki $B$, a więc blisko dwukrotny. Znacząco różne w porównaniu z tąż stawką są rozkłady przyrostów względnych obciążeń podatkowych. Co prawda w przypadku stawki przedziałowej odnotowano większe maksymalne wzrosty obciążeń, ale większy jest także udział działek, w których nastąpił spadek obciążeń podatkowych - w gminie zarówno wiejskiej, jak i miejskiej wysokość podatku zmniejszyła się dla ok. 21\% działek. Na wykresach 3 i 4 można również zaobserwować, że udział działek o wyższych przyrostach podatku niż maksymalny dla stawki B jest dość zróżnicowany w odniesieniu do gminy wiejskiej wynosi on jedynie $3 \%$, a gminy miejskiej $-19 \%$. Wszystko jest zależne od struktury wartości nieruchomości. Być może jednak stawka przedziałowa stanowi właściwy temat do dyskusji nad wysokością stawki podatku ad valorem.

Wykres 3. Rozkłady przyrostów względnych obciążeń podatkowych analizowanych działek gruntu - gmina wiejska
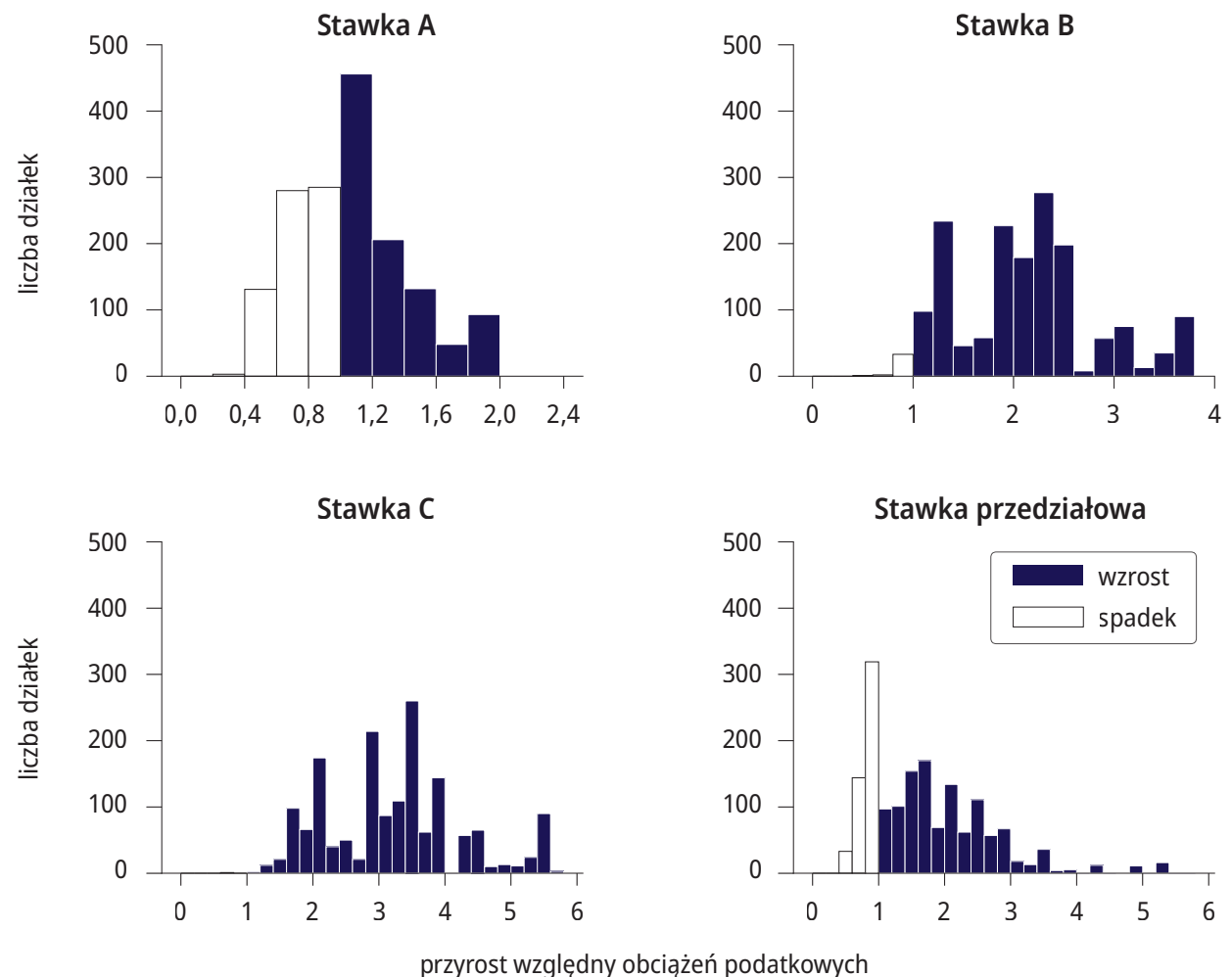

Źródło: opracowanie własne. 
Gdy porówna się wybrane miary przyrostów względnych obciążeń podatkowych stawki B oraz stawki przedziałowej przedstawione na wykresach 3 oraz 4, można zauważyć, że poszczególne kwartyle przyrostów (pierwszy, mediana i trzeci) są niższe w przypadku stawek przedziałowych niż stawek B. Dopiero powyżej trzeciego kwartylu pojawia się mniejsza dla gminy wiejskiej i większa dla gminy miejskiej grupa działek gruntu o wyższych przyrostach obciążeń podatkowych przy stawkach przedziałowych. Stawka A, jako stawka najniższa, powoduje niższe przyrosty obciążeń podatkowych, natomiast stawka C - najwyższe. Dotyczy to zarówno średnich przyrostów, jak i pozostałych miar. Wyższe maksymalne przyrosty obciążeń wystąpiły w przypadku działek zlokalizowanych w gminie wiejskiej.

Tabela 3. Wybrane miary struktury przyrostów względnych obciążeń podatkowych analizowanych działek gruntu w gminie wiejskiej

\begin{tabular}{|l|c|c|c|c|}
\hline $\begin{array}{c}\text { Miara struktury przyrostu obciążenia } \\
\text { podatkowego }\end{array}$ & Stawka A & Stawka B & Stawka C & $\begin{array}{c}\text { Stawka } \\
\text { przedziałowa }\end{array}$ \\
\hline Średnia & 1,07 & 2,14 & 3,22 & 1,72 \\
\hline Odchylenie standardowe & 0,34 & 0,68 & 1,02 & 0,91 \\
\hline Minimum & 0,25 & 0,50 & 0,76 & 0,48 \\
\hline Kwartyl pierwszy & 0,78 & 1,55 & 2,33 & 0,98 \\
\hline Mediana & 1,07 & 2,15 & 3,22 & 1,52 \\
\hline Kwartyl trzeci & 1,27 & 2,54 & 3,80 & 2,23 \\
\hline Maksimum & 1,91 & 3,82 & 5,73 & 5,25 \\
\hline
\end{tabular}

Źródło: opracowanie własne.

Tabela 4. Wybrane miary struktury przyrostów względnych obciążeń podatkowych analizowanych działek gruntu w gminie miejskiej

\begin{tabular}{|l|c|c|c|c|}
\hline $\begin{array}{c}\text { Miara struktury przyrostu obciążenia } \\
\text { podatkowego }\end{array}$ & Stawka A & Stawka B & Stawka C & $\begin{array}{c}\text { Stawka } \\
\text { przedziałowa }\end{array}$ \\
\hline Średnia & 0,98 & 1,96 & 2,94 & 2,07 \\
\hline Odchylenie standardowe & 0,28 & 0,55 & 0,83 & 0,99 \\
\hline Minimum & 0,55 & 1,10 & 1,65 & 0,63 \\
\hline Kwartyl pierwszy & 0,76 & 1,53 & 2,29 & 1,27 \\
\hline Mediana & 0,89 & 1,78 & 2,67 & 1,87 \\
\hline Kwartyl trzeci & 1,27 & 2,54 & 3,81 & 2,65 \\
\hline Maksimum & 1,56 & 3,12 & 4,68 & 4,60 \\
\hline
\end{tabular}

Źródło: opracowanie własne. 
Wykres 4. Rozkłady przyrostów względnych obciążeń podatkowych analizowanych działek gruntu - gmina miejska

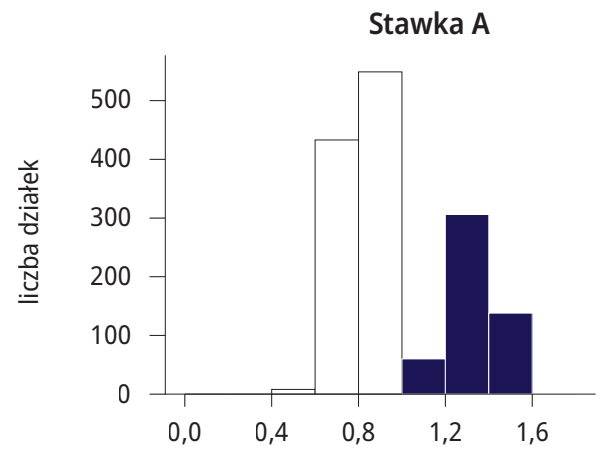

Stawka C

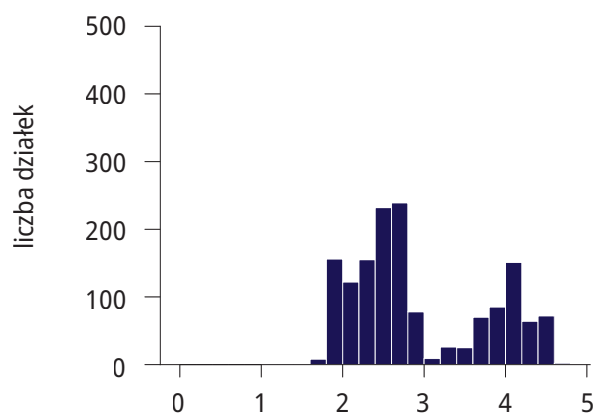

Stawka B

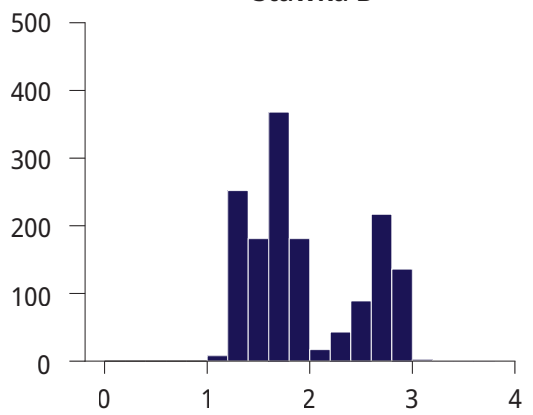

Stawka przedziałowa

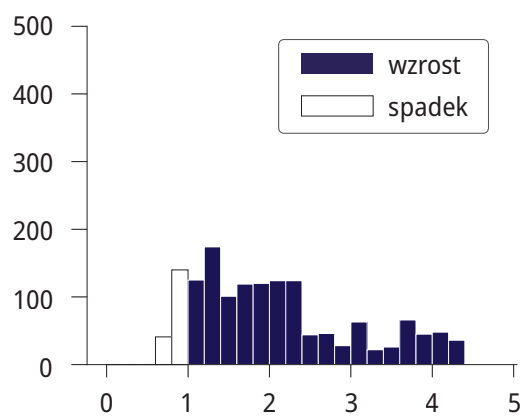

przyrost względny obciążeń podatkowych

Źródło: opracowanie własne.

\section{Analiza przesunięcia wysokości obciążeń podatkowych pomiędzy} nieruchomościami

Jednym z warunków spełnienia postulatów większej sprawiedliwości podatkowej oraz wyższej efektywności podatku od nieruchomości wysuwanych w literaturze i dyskusjach nad podatkiem katastralnym jest przesunięcie obciążeń podatkowych. Jeżeli do takiego przesunięcia by nie doszło, czyli nie zmieniłaby się kwota opodatkowania nieruchomości, reforma podatku od nieruchomości zostałaby zredukowana do zmiany nazwy tegoż podatku. W wyniku wprowadzenia podatku katastralnego na terenie każdej gminy przesunięcie obciążeń podatkowych zaszłoby niejako samoczynnie, ponieważ nieruchomości o tych samych powierzchniach mają różną wartość katastralną ze względu na atrakcyjność lokalizacji i cechy nieruchomości, które są uwzględniane w procesie wyceny. Na wykresach 5 i 6 zobrazowano rozkłady wysokości podatków od nieruchomości oraz od wartości nieruchomości przy stawce A w odniesieniu do analizowanych działek zlokalizowanych w gminach wiejskiej oraz miejskiej. Działki, w przypadku 


\section{Wykres 5. Rozkłady wysokości podatków od nieruchomości i ad valorem (stawka A) dla ana- lizowanych działek gruntu w gminie wiejskiej}

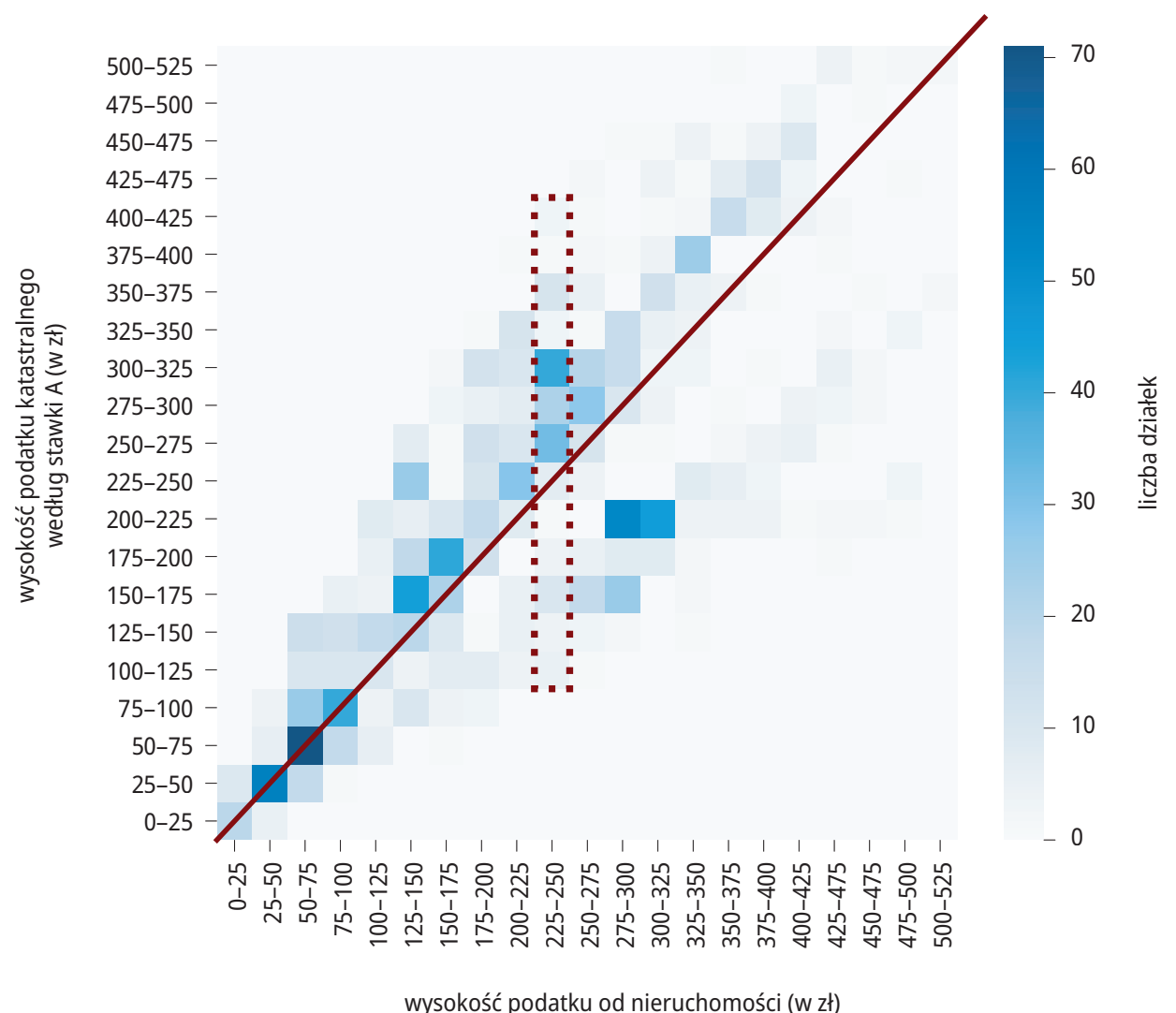

Źródło: opracowanie własne.

których wysokość podatku katastralnego byłaby wyższa niż podatku od nieruchomości, znajdują się powyżej przekątnej oznaczonej czarną linią. Działki, dla których podatek od wartości przy stawce A byłby niższy, na wykresie są poniżej przekątnej. Jak już wspomniano, przy stawce A nastąpiłby wzrost podatku w przypadku 57\% działek zlokalizowanych w gminie wiejskiej i 34\% działek w gminie miejskiej. Analiza wykresów wskazuje, że w wyniku zastąpienia podatku od nieruchomości podatkiem ad valorem zaszłyby znaczące zmiany w obciążeniach podatkowych poszczególnych działek gruntu. Dla każdego przedstawionego na wykresach przedziału wysokości podatku od nieruchomości odnotowano występowanie działek w więcej niż jednym przedziale podatku katastralnego. Przykładowo w gminie wiejskiej działki, dla których wysokość podatku od nieruchomości wynosi od 225 do 250 zł, po zastosowaniu stawki A byłyby obciążone podatkiem od wartości w wysokości od 100 do 425 zł, a więc przedział byłby szerszy. Na wykresie 5 działki te oznaczono linią kropkowaną. Gdy działki gruntu byłyby obciążone taką samą 


\section{Wykres 6. Rozkłady wysokości podatków od nieruchomości i ad valorem (stawka A) dla ana- lizowanych działek gruntu w gminie miejskiej}

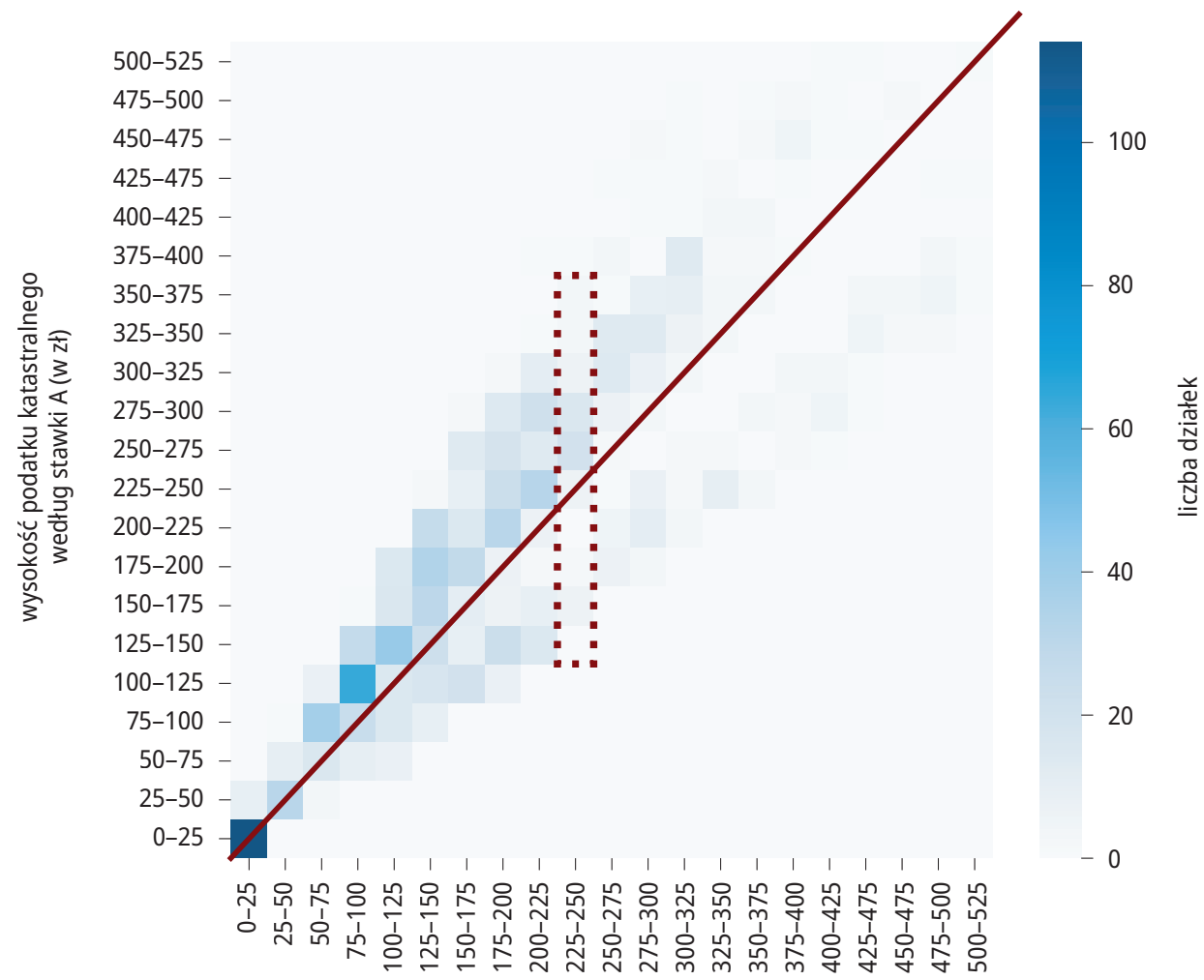

wysokość podatku od nieruchomości (w zł)

Źródło: opracowanie własne.

wysokością podatku od nieruchomości i podatku katastralnego, skupiły się na wykresach 5 i 6 wokół wspomnianej wcześniej przekątnej. Podobna sytuacja, a więc przesunięcie obciążeń podatkowych pomiędzy działkami, wystąpiła w gminie miejskiej (por. wykres 6). Ze względu na to, że w gminie miejskiej nastąpiłby spadek wysokości podatku (dla stawki A) w przypadku większej liczby działek, na wykresie 6 więcej punktów znajduje się poniżej przekątnej. Znaczne przesunięcie obciążeń podatkowych widoczne na wykresach dowodzi, że reforma opodatkowania nieruchomości nie byłaby jedynie zastąpieniem jednego podatku innym, ale skutkowałaby zmianami w funkcjonowaniu całego rynku nieruchomości.

W tabeli 5 przedstawiono, jaki odsetek działek w obu analizowanych zbiorach cechuje się podatkiem od wartości w wysokości zbliżonej do wysokości podatku od nieruchomości. Zaprezentowane dane wskazują, że im wyższa stawka podatku katastralnego, tym mniejszy odsetek działek gruntu odznaczających się wysokością podatku zbliżoną do obecnej. Przykładowo 
w przypadku gminy wiejskiej przy stawce A ponad 17\% działek byłoby obciążone kwotą, która różniłaby się od obecnej o mniej niż 5\%. Przy stawce C nie byłoby takiej działki. Jest to dość naturalne, ponieważ wyższe stawki procentowe podatku ad valorem przenoszą obciążenia podatkowe działek w coraz wyższe przedziały wartości, które znacząco się różnią od wysokości podatku od nieruchomości. Gdy zaś porówna się stawkę B i stawkę przedziałową, można zauważyć, że w przypadku tej drugiej odsetek działek o zbliżonej kwocie podatku jest wyższy zarówno przed zmianą podstawy opodatkowania, jak i po tej zmianie. Przemawia to za zmienną stawką podatku katastralnego w zależności od wartości nieruchomości.

Tabela 5. Odsetek działek o wybranych odchyleniach wysokości podatku ad valorem od bieżącej wysokości podatku od nieruchomości (w \%)

\begin{tabular}{|c|c|c|c|c|c|c|c|c|}
\hline \multirow{2}{*}{$\begin{array}{c}\text { Odchylenie } \\
\text { od bieżącej } \\
\text { wysokości } \\
\text { podatku }\end{array}$} & \multicolumn{2}{|c|}{ Stawka A } & \multicolumn{2}{c|}{ Stawka B } & \multicolumn{2}{c|}{ Stawka C } & \multicolumn{2}{c|}{$\begin{array}{c}\text { Stawka } \\
\text { przedziałowa }\end{array}$} \\
\cline { 2 - 9 } & $\begin{array}{c}\text { gmina } \\
\text { wiejska }\end{array}$ & $\begin{array}{c}\text { gmina } \\
\text { miejska }\end{array}$ & $\begin{array}{c}\text { gmina } \\
\text { wiejska }\end{array}$ & $\begin{array}{c}\text { gmina } \\
\text { miejska }\end{array}$ & $\begin{array}{c}\text { gmina } \\
\text { wiejska }\end{array}$ & $\begin{array}{c}\text { gmina } \\
\text { miejska }\end{array}$ & $\begin{array}{c}\text { gmina } \\
\text { wiejska }\end{array}$ & $\begin{array}{c}\text { gmina } \\
\text { miejska }\end{array}$ \\
\hline $\pm 5 \%$ & 17,20 & 4,42 & 1,22 & brak & brak & brak & 9,67 & 3,68 \\
\hline $\pm 10 \%$ & 24,85 & 13,25 & 2,51 & 0,07 & 0,06 & brak & 17,14 & 6,49 \\
\hline $\pm 20 \%$ & 45,35 & 40,76 & 8,02 & 0,54 & 0,12 & brak & 25,46 & 17,74 \\
\hline
\end{tabular}

Źródło: opracowanie własne.

\section{Symulacja zastosowania jednej stawki podatku katastralnego w analizowanych gminach}

O skali problemów związanych z jednolitą stawką stosowaną w gminach o różnym poziomie wartości nieruchomości można nieco powiedzieć na podstawie danych przedstawionych na wykresach 7 oraz 8. Za podstawę przyjęto stawkę B i dokonano niejako zamiany stawek podatku między analizowanymi gminami. Mianowicie w przypadku gminy wiejskiej wykorzystano stawkę ustaloną dla gminy miejskiej, a w odniesieniu do gminy miejskiej zastosowano stawkę określoną dla gminy wiejskiej. Przyjęcie dla gminy wiejskiej - o niższych przeciętnych wartościach gruntu - stawki niższej skutkowało bardzo niekorzystnym z perspektywy budżetu gminy obniżeniem wpływów podatkowych. Stawka podatku, która w jednej gminie (o wyższych wartościach nieruchomości) miała dwukrotnie zwiększyć wpływy do budżetu gminy, zastosowana w gminie o niższych wartościach nieruchomości spowodowała spadek tychże wpływów. Zaznaczone kolorem białym słupki histogramu przedstawionego na wykresie 7 obejmują blisko 71\% analizowanych działek gruntu w gminie wiejskiej. W przypadku tak znacznego odsetka działek gruntu nastąpiłby spadek obciążeń podatkowych.

Zupełnie inaczej przedstawia się sytuacja w gminie miejskiej w przypadku zastosowania wobec analizowanych w niej gruntów stawki B z gminy wiejskiej. Tym razem wpływy do budżetu gminy zamiast wzrosnąć dwukrotnie, zwiększyłyby się prawie pięciokrotnie. Wszystkie działki 
Wykres 7. Rozkłady przyrostów względnych obciążeń podatkowych analizowanych działek gruntu według stawki B gminy miejskiej - gmina wiejska

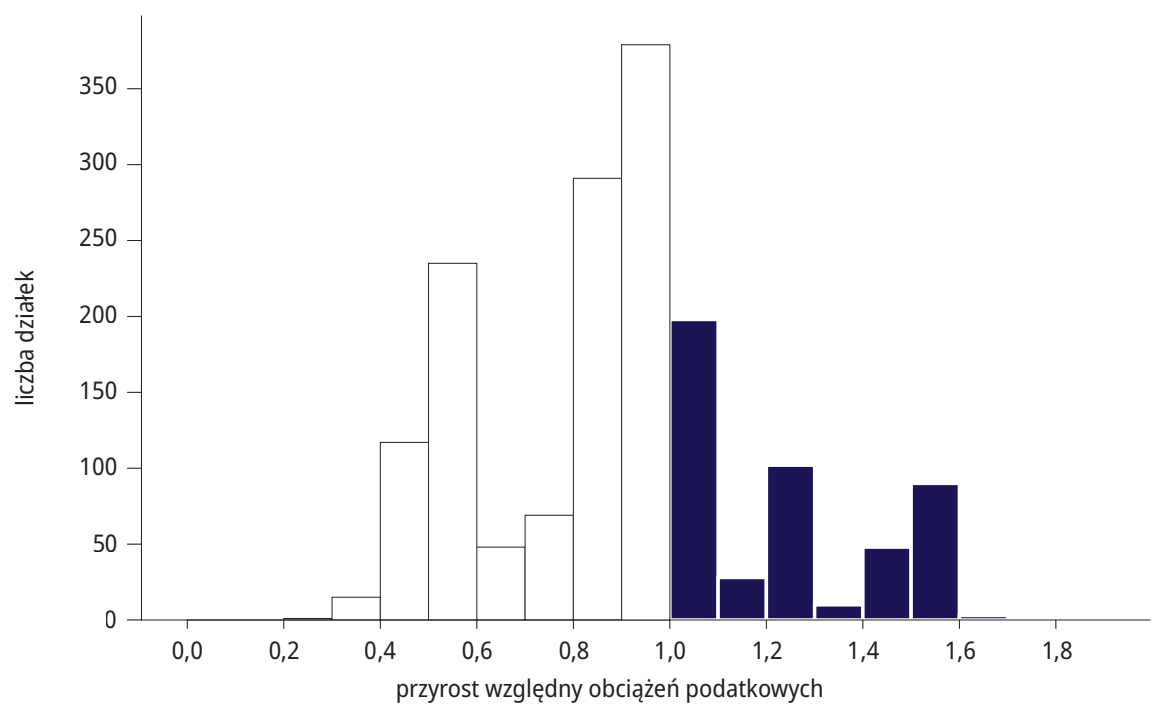

Źródło: opracowanie własne.

Wykres 8. Rozkłady przyrostów względnych obciążeń podatkowych analizowanych działek gruntu według stawki B gminy wiejskiej - gmina miejska

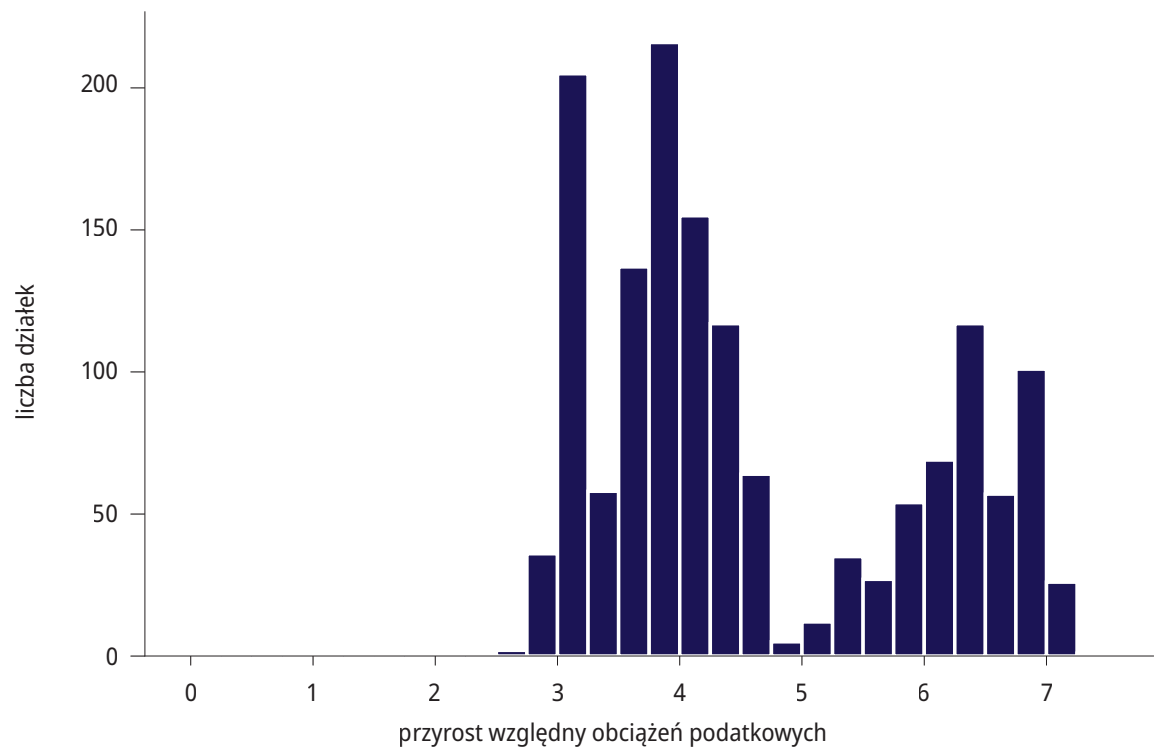


zostałyby obciążone wyższym kwotowo podatkiem w porównaniu z podatkiem od nieruchomości. Skala tego wzrostu wyniosłaby od 159\% do 636\%. W "najłagodniejszym” wariancie podmiot, na którym ciąży obowiązek podatkowy, musiałby się liczyć z podatkiem ponaddwuipółkrotnie wyższym niż w przypadku podatku od nieruchomości. W najgorszym wypadku wzrost obciążenia byłby ponadsiedmiokrotny (wykres 8). Taki wzrost obciążeń podatkowych z pewnością nie spotkałby się z poparciem społecznym. Przedstawione wyniki świadczą zaś o dużym problemie, jakim jest standaryzowanie stawki podatku od wartości nieruchomości. Stawka, która w założeniu ma zwiększyć dochody podatkowe w jednej gminie, zastosowana w innej daje zupełnie inne rezultaty. Może bowiem powodować spadek dochodów lub ich bardzo duże zwiększenie idące w parze ze znacznym wzrostem obciążeń podatkowych poszczególnych przedmiotów opodatkowania.

\section{Podsumowanie}

W artykule przedstawiono problematykę zastąpienia podatku od nieruchomości, którego podstawą jest powierzchnia mienia nieruchomego, podatkiem katastralnym liczonym od wartości nieruchomości. Badanie zostało ukierunkowane na aspekt ekonomiczny reformy opodatkowania nieruchomości. Ustalono bieżące obciążenia podatkowe i na podstawie wartości ponad 3 tys. działek gruntu przeznaczonych lub wykorzystywanych do celów mieszkaniowych zaproponowano kilka stawek procentowych podatku ad valorem. Wyniki symulacji zmian obciążeń podatkowych z zastosowaniem tych stawek wskazały na pewne ważne kwestie. Po pierwsze, nie można jednoznacznie stwierdzić, że podatek katastralny doprowadzi do znacznego wzrostu obciążeń podatkowych. Kwestia proporcji między działkami, które cechuje wzrost wysokości płaconego podatku, a tymi, dla których charakterystyczny jest spadek obciążeń, zależy od przyjętej stawki podatku i wartości nieruchomości. W przypadku stawek zapewniających takie same wpływy do budżetu gminy, jakie generuje podatek od nieruchomości, istotna część przedmiotów opodatkowania może być obciążona kwotą podatku niższą niż obecna. Dopiero stawki zwielokrotniające wpływy do budżetu gminy sprawiają, że większość działek lub nawet wszystkie są obarczone wyższą kwotą, w skrajnych przypadkach wielokrotnie wyższą. Po drugie, zastosowanie stawek ustalanych dla przedziałów wartości nieruchomości zmniejsza liczbę działek, dla których nastąpiłby wzrost obciążeń podatkowych. Tym samym ogranicza negatywne konsekwencje reformy opodatkowania, które mogą się wiązać z wprowadzeniem jednorodnej stawki mającej zapewnić podobne wpływy do budżetu gminy. Po trzecie, wykazano, że zmiana podstawy opodatkowania nieruchomości znacząco przesuwa obciążenia podatkowe. Nie jest więc jedynie prostym zastąpieniem jednego podatku innym, lecz ma szanse wywołać pożądaną przez rządzących reakcję rynku - wskazywaną jako zaletę podatku katastralnego - a więc zaprzestanie spekulacyjnego przetrzymywania gruntów niezabudowanych. W podsumowaniu należy stwierdzić, że zastosowanie jednej stawki podatku w skali całego kraju wydaje się mało realne. Rozziew w wartościach gruntów w różnych częściach Polski jest znaczny. Można przewidywać duży opór społeczny przed drastycznymi dysproporcjami w opodatkowaniu nieruchomości w różnych gminach. Co więcej, jak przedstawiono w badaniu, jedna stawka stosowana 
w poszczególnych gminach może mieć odmienne skutki dla ich dochodów - w jednych gminach może zmniejszać wpływy, a w innych je zwiększać.

Dyskusja na temat opodatkowania wartości nieruchomości na pewno jeszcze potrwa. Wydaje się, że im dłużej będzie wstrzymywana decyzja o reformie podatku od nieruchomości, tym trudniej będzie wprowadzić zmiany. Przyzwyczajenie społeczeństwa do bardzo niskiego podatku od nieruchomości może zaś z biegiem lat stać się na tyle silne, że uniemożliwi rządzącym wprowadzenie podatku potencjalnie wyższego. Nie zmienia to jednak faktu, że badania nad taką reformą są potrzebne, by stworzyć na przyszłość fundamenty pod rzeczywiste działania techniczne, organizacyjne i polityczne.

\section{Bibliografia}

Brzeski W.J., Frenzen R., Uzasadnienie reformy formuły ad valorem w gospodarkach transformacji, „Świat Nieruchomości" 1999, nr 28.

Dmytrów K., Gdakowicz A., Putek-Szeląg E., Methods of Analyzing Qualitative Variable Correlation on the Real Estate Market, „Real Estate Management and Valuation” 2020, t. 28, nr 1, https://doi.org/10.2478/remav-2020-0007.

Dmytrów K., Gdakowicz A., Putek-Szeląg E., Statistical Relations of the Qualitative Attributes of Real Properties Subject to Mass Appraisal, „Folia Oeconomica Stetinensia” 2019, t. 19, nr 2, https://doi.org/10.2478/foli-2019-0011.

Doszyń M., Algorithm of Real Estate Mass Appraisal with Inequality Restricted Least Squares (IRLS) Estimation, „Journal of European Real Estate Research" 2020, t. 13, nr 2, https://doi.org/10.1108/jerer-11-2019-0040.

Etel L., Reforma opodatkowania nieruchomości w Polsce, Wydawnictwo Temida 2, Białystok 1998.

Felis P., Konsekwencje reformy systemu podatków od nieruchomości w Polsce [w:] Konsekwencje zmiany obciązeń podatkowych w Polsce, red. J. Głuchowski, K. Piotrowska-Marczak, J. Fila, Difin, Warszawa 2013.

Felis P., System opodatkowania nieruchomości w Polsce, „Infos" 2012, 14(128), Biuro Analiz Sejmowych.

Foryś I., Putek-Szeląg E., A Non-Classical Model of Mass Valuation of Agricultural Property, „Real Estate Management and Valuation" 2018, t. 26, nr 4, https://doi.org/10.2478/remav-2018-0039.

Głuszak M., Marona B., Podatek katastralny. Ekonomiczne uwarunkowania reformy opodatkowania nieruchomości, Poltext, Warszawa 2015.

Głuszak M., Marona B., Oleksy P., Non-Fiscal Incentives and Challenges of Property Tax Reform in Poland, „World of Real Estate Journal" 2013, nr 4(86).

Gnat S., Analysis of the Effects of Replacing Current Property Tax with Ad Valorem Property Tax in a Sample Municipality, „Folia Oeconomica Stetinensia” 2009, t. 8, nr 1.

Gnat S., Powierzchniowy a katastralny system opodatkowania nieruchomości - symulacja wybranych skutków fiskalnych, „Annales Universitatis Mariae Curie-Skłodowska. Sectio H. Oeconomia” 2016, t. 50, nr 1, https://doi. org/10.17951/h.2016.50.1.371.

Hełdak M., Stacherzak A., Baumane V., Real Estate Value Tax Based on the Latvian Experience, „Real Estate Management and Valuation" 2014, t. 22, nr 4, https://doi.org/10.2478/remav-2014-0037.

Hozer J. et al., Ekonometryczny algorytm masowej wyceny nieruchomości gruntowych, Uniwersytet Szczeciński, Stowarzyszenie Pomoc i Rozwój, Szczecin 1999.

Laskowska E., Property Tax Systems in Selected European Union Countries and the Proposed Tax Reform in Poland, "Scientific Journal Warsaw University of Life Sciences - SGGW. Problems of World Agriculture" 2015, t. 15(30), nr 4. 
Małkowska A. et. al., Spatial Interdependence in Property Taxation. The Case of Polish Municipalities, „Equilibrium. Quarterly Journal of Economics and Economic Policy" 2018, t. 13, nr 2, https://doi.org/10.24136/eq.2018.014. Milewska A., Problemy opodatkowania nieruchomości w Polsce - przegląd wybranych aspektów, „Annales Universitatis Mariae Curie-Skłodowska. Sectio H. Oeconomia" 2016, t. 50, nr 1, https://doi.org/10.17951/h.2016.50.1.391. Piekut J., Wady i zalety wprowadzenia podatku katastralnego, „Kwartalnik Naukowy Uczelni Vistula” 2014, nr 3(41). Pietraszko I., Czy powinniśmy obawiać się podatku od wartości nieruchomości?, „Samorząd Terytorialny” 2003, nr 12. System kalibracji macierzy wpływu atrybutów w szczecińskim algorytmie masowej wyceny nieruchomości, red. M. Doszyń, Wydawnictwo Naukowe Uniwersytetu Szczecińskiego, Szczecin 2020.

Wójtowicz K., Analiza potencjalnych skutków reformy systemu opodatkowania nieruchomości w Polsce [w:] Finanse publiczne, red. A. Pomorska, Wydawnictwo UMCS, Lublin 2006.

\section{Akty prawne}

Ustawa z dnia 21 sierpnia 1997 r. o gospodarce nieruchomościami (Dz.U. 2020, poz. 1990, ze zm.). 